\title{
Exploration Design Development Borobudur Chair Based on Perspective of Industrial Furniture in Surakarta
}

\author{
Rahmanu Widayat \\ Departement of Interior Design, Faculty \\ of Arts and Design, Universitas Sebelas \\ Maret (UNS) Indonesia \\ rahmanuwidayat@staff.uns.ac.id
}

\author{
Anung B Studyanto \\ Departement of Interior Design, Faculty \\ of Arts and Design, Universitas Sebelas \\ Maret (UNS) Indonesia \\ anungbs@staff.uns.ac.id
}

\author{
If. Bambang Sulistyono \\ Departement of Interior Design, Faculty \\ of Arts and Design, Universitas Sebelas \\ Maret (UNS) Indonesia \\ ifbbssk@staff.uns.ac.id
}

\begin{abstract}
Borobudur seat design was a study result as chair reconstruction from Karmawibhangga relief in Borobudur temple. The exploration has been done by the perspective of fine art and design with wangun (beautiful) and aeng (weird) as design creativity and arts. Regional of Surakarta and around it have a lot of industrial furniture, the problem is how can the Borobudur seat being explored by industrial furniture doer in Surakarta, the questions 1) What concept and how it applied? 2) How it can be seen? And 3) how is the perspective of industrial furniture doer to Borobudur seat as the result of design exploration? The using of method is read by processing of furniture design creation, and it is explained based on the fact of furniture design conceptual, and using perceptional theoretical. The interesting result and discussion from furniture industrial doer before applying the design exploration concepts are marketing survey, taste, and consumer culture that will be reached, climate (related to material selection), finishing, furniture delivering process, price, and quality. After that, the design concepts are applied like designer always do the redesign, because this is the most suitable concepts. The form of design as the result of exploration has a lot of variant depend on area, market segmentation, taste, and consumer culture which is aimed. Related to the perception of industrial doer that really optimist to the product of Borobudur seat based on exploration from industrial exploration which is really demanding by consumer.
\end{abstract}

Keyword: exploration, Borobudur Chair, furniture industry

\section{INTRODUCTION}

Our research result of Borobudur Chair in 2015 which is in the form of the visual reconstruction chair of the Borobudur Temple relief (Widayat, Studyanto, and Sholahuddin, 2015) has inspired us to redesign the Borobudur Chair using the concept of wangun or beautiful (Widayat, Studyanto, and Sholahuddin, 2016). It was continued by redesigning the Borobudur Chair using the concept of aèng or strange ((Widayat, Studyanto, and Sholahuddin, 2017). In 2018, we explore the Borobudur Chair using the perspective of business actors in furniture industry in Surakarta as well as its marketing possibility ((Widayat, Studyanto, and Sholahuddin, 2018).

This study is important due to the history of furniture in Java which was stopped and the assumption that Javanese people do not have the culture of sitting on the chair. Based on our research, the culture of sitting on the chair has existed since a thousand year ago. It is viewed from the chair of Borobudur Temple relief built in the $9^{\text {th }}$ century (Borobudur Chair). This phenomenon does not receive much attention from either the academicians or the practitioners. It indicates that there was a gap of the study related to Borobudur Chair. Therefore, we conduct the research and redesign of the Borobudur Chair from the practitioner's perspective to make it well-known and beneficial for the society. The reconstruction of the Borobudur Chair has been conducted, while the exploration has been and was being done using various concepts and approaches. However, there is the interesting finding which states that the customer's desire, location, climate, and culture determine whether or not the exploration development of Borobudur Chair design is accepted.

\section{LITERATURE AND THEORY}

The concept used in exploring the Borobudur Chair was redesign concept which is the design that has been formed into the product. The product is reanalyzed and redesigned from the beginning as a whole or a part (Widayat, 2010: 124). There are several concepts that can assist the redesign which are done by changing the form: simplification, distortion, destruction, stylization, or combination among the entire structure of the form (mix) (Susanto, 2012:105). The option of redesign concept depends on the market survey and the designer's background to generate the appropriate concept. The perspective of business actors in furniture industry in the form of perception or interpretation is strengthened by the interpretation theory. It is stated that interpreting should understand the demanded context (Sudjiman and Zoest, 1992: 103 ), which is the environment of furniture industry in Surakarta.

\section{DATA AND METHODS}

The data were collected from the business actor of furniture industry in Surakarta through Forum Group Discussion (FGD) related to the exploration concept of Borobudur Chair, the implementation of the concept, the form of the design, and the business actor's perspective in furniture industry in Surakarta in term of the marketing. In relation to the design creation, the method used was viewed by the creation process of the furniture design through the data-consideration of the 
FGD result and was continued to the sectional redesign process.

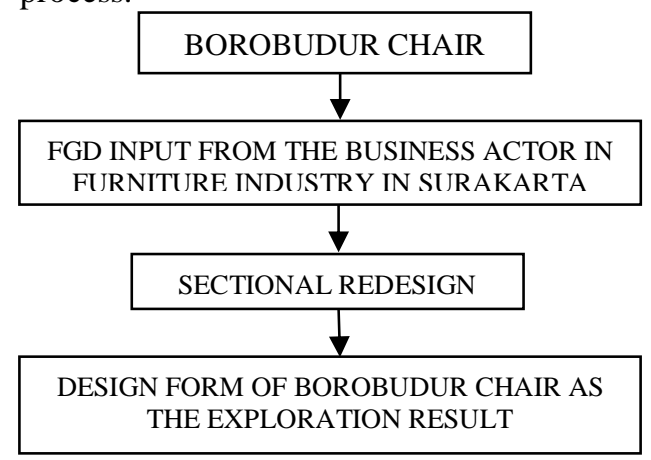

Diagram 1. Exploration Stages of Borobudur Chair from the Perspective of Business Actors in Furniture Industry

\section{RESULT AND DISCUSSION}

Based on the problems emerged from the article entitled "The Exploration of Design Development of Borobudur Chair based on the Perspective of Business Actor in Furniture Industry in Surakarta", the result and discussion are proposed as follows:

The concept implemented in design exploration uses the consideration of the market survey either domestic or abroad. The market segmentation which is considered includes the targeted customer's desire and culture, climate (related to material determination), finishing, the process of furniture delivery, price, and quality. Afterward, the redesign concept is implemented not as a whole yet sectional to preserve the typical character of Borobudur Chair.

\section{a. Design Form}

The design form as the exploration result has many varieties depends on the area, market segmentation, desire, and the targeted customer's culture. The example given is the domestic marketing which requires the consideration of the ethnicity and culture aspect that causes great influence since each tribe has a different concept, behavior, and artifact heritage. Meanwhile, the overseas marketing can be identified by each area: Europe, America, Middle East, and Africa, so many considerations are needed.

b.

The Perception of Business Actor on

the Borobudur Chair as the Result of the Design Exploration

Based on the data collected through FGD, the business actors in furniture industry is optimistic to the exploration result of Borobudur Chair which is the customer's most-wanted product. This belief is based on the interpretation that the market survey is done correctly. Another alternative to make the product received by the market is by creating the market desire which is suitable to what the industrial sector wants. The different example that can be inspired by its success is the design of automotive products and electronic products that can lead to the customer's desire.

\section{CONCLUSION}

The conclusion of this problem, result, and discussion related to Borobudur Chair that is explored by the actors in furniture industry in Surakarta has been made. First, the exploration of design development of Borobudur Chair uses the concept consideration generated from the market survey of the area either domestic or overseas. Second, the market segmentation requires to be studied in terms of the customer's desire, culture, climate, finishing, delivery process, price, and quality. Based on the data, the design process is continued by the designer using the consideration to preserve the featured original character of Borobudur Chair.

The design form of the exploration result of Borobudur Chair has various types depends on the targeted customer's area, market segmentation, desire, and culture. It is also influenced by the designer's experience background related to the typical characteristics or designer's personal style. It is interesting since the same source of the idea will generate the different result if it is redesigned.

The business actors in furniture industry are optimistic that the product of Borobudur Chair based on the exploration of industrial field is desired by the customers either from domestic or overseas inasmuch as the market survey is done correctly.

\section{ACKNOWLEDGMENTS}

We thank the rector of Universitas Sebelas Maret (UNS) Surakarta and the chief of LPPM UNS that have received the research proposal entitled: "The Exploration of Design Development of Borobudur and have funded through PNBP UNS. We also thank the business actors in furniture industry in Surakarta as the informants in Forum Group Discussion that has been conducted.

\section{REFERENCES}

[1] Widayat, Rahmanu; Studyanto, Anung B.; dan Sholahuddin. 2015. Rekonstruksi "Kursi Borobudur" (Untuk Menunjang Industri Kreatif), Penelitian Unggulan Perguruan Tinggi (PUPT) Tahap I, Fakultas Seni Rupa dan Desain, Universitas Sebelas Maret Surakarta.

[2] Widayat, Rahmanu; Studyanto, Anung B.; dan Sholahuddin. 2016. Rekonstruksi "Kursi Borobudur" (Untuk Menunjang Industri Kreatif), Penelitian Unggulan Perguruan Tinggi (PUPT) Tahap II, Fakultas Seni Rupa dan Desain, Universitas Sebelas Maret Surakarta.

[3] Widayat, Rahmanu; Studyanto, Anung B.; dan Sulistyono, If. Bambang. 2017. Eksplorasi Pengembangan Kursi Borobudur (Tahap I), Penelitian Penciptaan dan Penyanjian Seni (P3S), DIPA Universitas Sebelas Maret Surakarta.

[4] Widayat, Rahmanu; Studyanto, Anung B.; dan Sulistyono. If. Bambang, 2018. Eksplorasi Pengembangan Kursi Borobudur (Tahap II), Penelitian Penciptaan dan Penyanjian Seni (P3S), DIPA Universitas Sebelas Maret Surakarta (dalam proses).

[5] Widayat, Rahmanu. 2010. Kumpulan Istilah Desain Interior. Solo: FSSR Publishing.

[6] Susanto, Mikke. 2012. Diksi Rupa Kumpulan Istilah dan Gerakan Seni Rupa. Yogyakarta: DictiArt Lab \& Djagad Art House.

[7] Sudjiman, Panuti dan Zoest, Aart van. 1992. Serba-Serbi Semiotika. Jakarta: PT Gramedia Pustaka Utama 
